\title{
Missing Investment Treaties
}

\section{Rodrigo Polanco Lazo*, Valentino Desilvestro* and Azernoosh Bazrafkan*}

\begin{abstract}
This article presents the situation of 'Missing Investment Treaties' (MITs), defined as those International Investment Agreements (IIAs) that have been concluded by States, but their texts (and in some cases their existence) are not publicly available or incomplete. In order to determine the number of MITs, we examined the text and language availability of IIAs concluded by countries, that are publicly available, and we complemented that information with country-specific searches from international, governmental and private sources. In turn, the article explores possible explanations to this State's behaviour, using the following questions as guidelines: Why would countries sign agreements that are supposedly negotiated to promote, protect or liberalise foreign investment without making those texts available? If a text of an IIA is publicly available, does it correspond to the language of both contracting parties, only one of them, or of a third country? Is it possible to achieve IIAs' objectives if the text of the treaty is not available, or is it available only in one language? Might there be other reasons to sign these agreements?
\end{abstract}

\section{INTRODUCTION}

If we briefly examine the main provisions of International Investment Agreements (IIAs) — or in some cases, just their title-one may conclude that the main objectives of these agreements are the promotion and protection of foreign investment (and in some cases, also the liberalization and facilitation of cross-border investment flows).

In that context, IIAs appear to have been negotiated to 'signal' foreign investors the willingness of host states to create and maintain a stable and favourable investment climate which would in turn, attract increased foreign investment flows; ${ }^{1}$ or to further provide 'credible commitments' to foreign investors that are theoretically relevant to the investment decisions, for example, by providing access to Investor-

* All researchers at the World Trade Institute (WTI), University of Bern, in the 2015 Swiss Network for International Studies (SNIS) Project 'Diffusion of International Law: A Textual Analysis of International Investment Agreements'. The authors would like to thank three anonymous reviewers of the Journal of International Economic Law, for their helpful comments and suggestions.

1 Jason W. Yackee, 'Do Investment Promotion Agencies Promote Bilateral Investment Treaties?', in Andrea K. Bjorklund (ed.), Yearb Int Invest Law Policy 2013-2014 (New York: Oxford University Press, 2015) $529-52$, at 531-32.

(c) The Author(s) 2018. Published by Oxford University Press. All rights reserved. 
State Dispute Settlement (ISDS) for violations of standards of protection contained in IIAs, such as indirect expropriation and discriminatory or arbitrary regulation. ${ }^{2}$

Much of the critique against the current international investment treaty regime is based on this 'grand bargain' characteristic ${ }^{3}$ of these agreements. It can be argued whether investors can easily ascertain the depth of commitments of potential host states, and thus influence their investment decisions. Additionally, empirical studies on the effects of IIAs on increased investment flows often show contradictory results.

To this date, the literature has paid little consideration to the fact that the text of an important share of existing IIAs is currently not publicly available, further referred to as 'Missing Investment Treaties' (MITs). This article has two objectives. Firstly, it draws the attention to the MITs showing that while some agreements could be found by looking into not-easily accessible governmental publications, some others could not be retrieved at all. Secondly, it provides quantitative evidence about the determinants of MITs. It is shown that the text of treaties signed by countries with low institutional quality, as measured by the World Governance Indicators, are statistically more likely to be missing.

This article is structured as follows: after this introduction, the second section provides a background review on the effect of IIAs on foreign direct investment (FDI) flows and whether the availability of IIAs has been considered in the existing literature. The third section details the number of IIAs that is publicly available, and the methodology used to find missing treaties from different sources. The fourth section provides descriptive statistics of MITs and econometric evidence on their determinants. The fifth section focuses on the language availability of IIAs. In section six we map the common features of IIAs from countries with the largest number of MITs to assess if there is a common pattern between them; and in the final section and the conclusion we explore if other motives behind investment treaty adoption could explain this phenomenon.

\section{ECONOMIC AND POLITICAL EFFECTS OF IIAS: A}

\section{LITERATURE REVIEW}

In spite of a growing body of literature, the extent to which IIAs promote FDI remains unclear, and research has been mostly focused on bilateral investment treaties (BITs), which represent the large majority of IIAs (around 90\%). A comprehensive summary of the literature on the effects of BITs on FDI flows is beyond the scope of this article. Interested readers can refer to the work of Pohl, ${ }^{4}$ Bonnitcha,

2 Jason Webb Yackee, 'Do Bilateral Investment Treaties Promote Foreign Direct Investment? Some Hints from Alternative Evidence', 51 Virginia Journal of International Law (2010), at 397, at 403, 412-13. Jonathan Bonnitcha, Lauge N Skovgaard Poulsen and Michael Waibel, The Political Economy of the Investment Treaty Regime (Oxford: Oxford University Press, 2018), at 158.

3 Jeswald W. Salacuse and Nicholas P. Sullivan, 'Do BITs Really Work: An Evaluation of Bilateral Investment Treaties and Their Grand Bargain', 46 Harvard International Law Journal (2005), at 67, at 67.

4 Joachim Pohl, 'Societal Benefits and Costs of International Investment Agreements', OECD Working Papers on International Investment 2018/01 (2018), at http://www.oecd-ilibrary.org/finance-and-invest ment/societal-benefits-and-costs-of-international-investment-agreements_e5f85c3d-en (visited 27 March 2018). 
Poulsen and Waibel, ${ }^{5}$ the United Nations Conference on Trade and Development (UNCTAD), as well as Sauvant and Sachs, ${ }^{6}$ for a detailed overview of the relevant literature, which is largely inconclusive about the actual effects of IIAs on investment flows. Instead, this section will show that availability of IIAs and particularly of BITs texts has been largely overlooked by existing research. In turn, this has implications for the empirical literature on the effects of BITs on FDI.

According to both 'signalling' and 'commitment' theories, there are different causal mechanisms that can result in BITs increasing FDI.

Under signalling theories, IIAs provide investors with ex-ante information, as countries advertise their agreements, and therefore the commitments they are willing to make to foreign investors. ${ }^{7}$ Model specification has been shown to be very important for these theories. For instance, Neumayer and Spess used total inflows of FDI from 1970 to 2001 and the total number of BITs signed with Organization for Economic Co-operation and Development (OECD) countries as dependent and explanatory variable respectively. The authors found a very large effect of BITs on investment, with the effect being stronger for countries with lower institutional quality. ${ }^{8}$ The robustness of these results was questioned by Yackee. ${ }^{9}$ After replicating their econometric models with some minor modifications, he increased the sample size including data up to the year 2003, and also other agreements similar to BITs. This resulted in the vanishing of the large effect of BITs on FDI flows and the reversing of the relationship with the quality of institutions. ${ }^{10}$

Hallward-Driemeier analysed bilateral FDI flows for the years 1980-2000 and found that there is no statistically significant effect of BITs on FDI, and concluded that BITs are complements to good institutions, rather than substitutes. ${ }^{11}$ Similarly, Rose-Ackermann and Tobin, using total FDI for the period 1975-2000, found that BITs have little impact on FDI and that the effect is negative for countries characterized by high political risk, and positive for countries with lower risk. This raises doubts to the extent to which BITs can substitute for weak investment environment. $^{12}$

5 See Bonnitcha, Poulsen, and Waibel, above n 2, at 155-80.

6 Karl P. Sauvant and Lisa E. Sachs (eds), The Effect of Treaties on Foreign Direct Investment: Bilateral Investment Treaties, Double Taxation Treaties, and Investment Flows (Oxford: Oxford University Press, 2009).

7 Tim Büthe and Helen V. Milner, 'Bilateral Investment Treaties and Foreign Direct Investment: A Political Analysis', in Sauvant and Sachs (eds), above n 6, 171-224; Tim Büthe and Helen V. Milner, 'Foreign Direct Investment and Institutional Diversity in Trade Agreements: Credibility, Commitment, and Economic Flows in the Developing World, 1971-2007', 1 World Politics 66 (2014), at 88.

8 Eric Neumayer and Laura Spess, 'Do Bilateral Investment Treaties Increase Foreign Direct Investment to Developing Countries?’, 10 World Development 33 (2005), at 1567.

9 Jason W. Yackee, 'Do BITs Really Work? Revisiting the Empirical Link Between Investment Treaties and Foreign Direct Investment', in Sauvant and Sachs (eds), above n 6.

10 See Neumayer and Spess, above n 8.

11 Mary Hallward-Driemeier, Do Bilateral Investment Treaties Attract Foreign Direct Investment? Only a Bit? and They Could Bite, Policy Research Working Paper 3121 (The World Bank, 2003).

12 Jennifer Tobin and Susan Rose-Ackerman, 'Foreign Direct Investment and the Business Environment in Developing Countries: The Impact of Bilateral Investment Treaties', Yale Law and Economic Research Paper 293 (2005), at 1. 
Under commitment theories, the protection given by IIAs is directly relevant to investment decisions because they provide them with rights that are not available to competitors, or help them to solve hold-up problems. ${ }^{13}$ Using data for OECD countries during the years 1982-1997, Egger and Pfaffermayr found that BITs have a positive impact on the foreign stock of FDI. ${ }^{14}$ Their effect is estimated with more precision when taking into account only BITs in force, because of time lags between the signature and the ratification of the agreements. ${ }^{15}$ Indeed, according to the UNCTAD database, only $80 \%$ of the BITs signed up to February 2018 have entered into force. ${ }^{16}$

Yackee argues that the use of BITs counts is inappropriate for this purpose insofar as that methodology does not take into account content variation across BITs and does not control for other investment agreements that have very similar content and purpose to BITs. He claims that while the substantial promises to investors are to a certain extent similar, their credibility varies greatly. In particular, BITs display different degrees of guarantees with respect to enforcement. In order to address this shortcoming, he classified approximately one thousand BITs according to whether disputes settlement provisions are included and to which extend investors can have access to it, illustrating a very important shift over time towards stronger commitment devices, especially from the $90 \mathrm{~s}^{17}$ This classification is used by Berger ${ }^{18}$ to study whether variation in the provisions included in BITs affects FDI flows. His results show that FDI increases if BITs include pre-establishment national treatment and/or most-favoured-nation provisions. Investor-state dispute settlement provisions are found to be of minor significance. In a similar research setup, Berger and others do not find any evidence for stricter dispute settlement provisions in BITs having a consistent effect on FDI. ${ }^{19}$

But regardless their underlying theories, empirical literature on the IIAs effects on FDI have several shortcomings. First, the empirical evidence on the effect of IIAs on FDI is highly dependent on model and variables specification and on the degree to which reverse causality is dealt with. Studies also vary with respect to the channel through which IIAs are expected to increase FDI. Another limitation is endogeneity. Aisbett $^{20}$ shows that BITs are likely to be signed in presence of increased FDI flows and in the context of general changes in domestic policy of FDI destination

13 See Bonnitcha, Poulsen, and Waibel, above n 2, at 158.

14 Peter Egger and Michael Pfaffermayr, 'The Impact of Bilateral Investment Treaties on Foreign Direct Investment', 4 Journal of Comparative Economics 32 (2004), at 788.

15 Yoram Z. Haftel, 'Ratification Counts: US Investment Treaties and FDI Flows into Developing Countries', 2 Review of International Political Economy 17 (2010), at 348.

16 UNCTAD, 'International Investment Agreements Navigator' (February 2018), Invest Policy Hub http:// investmentpolicyhub.unctad.org/IIA/IiasByCountry\#iiaInnerMenu (visited 6 February 2018).

17 Jason Webb Yackee, 'Conceptual Difficulties in the Empirical Study of Bilateral Investment Treaties', 2 Brooklyn Journal of International Law 33 (2008), at 405.

18 Axel Berger et al, 'Do Trade and Investment Agreements Lead to more FDI? Accounting for Key Provisions Inside the Black Box', 2 International Economics and Economic Policy 10 (2012), at 247.

19 Axel Berger et al, 'More Stringent BITs, Less Ambiguous Effects on FDI? Not a Bit!', 3 Economics Letters 112 (2011), at 270.

20 Emma Aisbett, 'Bilateral Investment Treaties and Foreign direct Investment: Correlation versus Causation', in Sauvant and Sachs (eds), above n 6. 
countries. Once these factors are taken into account, the correlation between BITs and FDI vanishes. The fact that BITs are signed in a larger development context is supported by anecdotal evidence. For instance, interviews with BIT-negotiators for Pakistan confirm that the vast majority of their recent BITs were signed as a supplement to major investment initiatives with foreign countries and companies in specific sectors. $^{21}$

A third shortcoming of the vast majority of this literature is that BITs are considered as all alike, and therefore explanatory variables take the form of either counts of BITs, based on the signature date or entry into force date. In other words, the explanatory variable is an indicator for whether and/or how many BITs exist, rather than an indicator for absence/presence of specific rights granted to investors. It has been argued that the bulk of BITs present very similar provisions, with the most important change over time being the transfer of disputes from national to international institutions. ${ }^{22}$ Allee and Peinhardt have questioned this conclusion, showing that a considerable variation can be found in 1500 BITs with the respect to delegation of arbitration under ICSID rules. ${ }^{23}$ To our knowledge, some of the few contributions to the literature trying to estimate the effect of variation across BITs content on FDI flows come from Berger ${ }^{24}$ and Berger and others. ${ }^{25}$ Although these studies move in the right direction, they are very limited with respect to the number of BITs taken into consideration.

A fourth limitation of existing empirical studies, is that both 'signalling' and 'commitment' theories assume the general investor's knowledge of the existence of IIAs, and this has also been subject to debate. For instance, according to Poulsen in one survey by the European Commission with 300 European investors, only 10\% confirmed to use BITs in their decision, while to $50 \%$ of the participants BITs were unknown. $^{26}$ In contrast, UNCTAD has provided survey evidence that BITs are significant investment decision factors, especially for investors in transition economies. ${ }^{27}$ The pertinence of BITs for investors seems to depend on the size and economic sector in which investors are involved. ${ }^{28}$

The relevance of BIT's text availability in determining FDI is unclear. It remains an open question whether investors use BITs when taking investment decisions. In

21 Lauge N. Skovgaard Poulsen, 'The Importance of BITs for Foreign Direct Investment and Political Risk Insurance: Revisiting the Evidence', in Karl Sauvant (ed.), Yearbook on International Investment Law and Policy 2009-2010 (New York: Oxford University Press, 2010).

22 See Tobin and Rose-Ackerman, above n 12, Foreign Direct Investment and the Business Environment in Developing Countries.

23 Todd Allee and Clint Peinhardt, 'Delegating Differences: Bilateral Investment Treaties and Bargaining Over Dispute Resolution Provisions', 1 International Studies Quartely 54 (2010), at 1.

24 See Berger et al, above n 19, More stringent BITs, less ambiguous effects on FDI?

25 See Berger et al, above n 18, Do trade and investment agreements lead to more FDI?

26 See Poulsen, above $\mathrm{n} 21$.

27 UNCTAD, The Role of International Investment Agreements in Attracting Foreign Direct Investment to Developing Countries (New York: United Nations, 2010).

28 See Yackee, above n 17; Liesbeth Colen, Damiaan Persyn and Andrea Guariso, 'Bilateral Investment Treaties and FDI: Does the Sector Matter?’, 83 World Development issue C (2016), at 193; UNCTAD, ibid. 
his summary of qualitative surveys with investors, Poulsen has provided evidence that BITs are important in presence of discord with the host state after the investment has been made, rather than in the establishment phase. He obtained similar results when interviewing BIT-negotiators representing countries accounting for more than $40 \%$ of world total outward FDI. ${ }^{29}$ The World Bank has provided some evidence that investors only become interested in BITs after frictions arise. ${ }^{30}$

The implications of MITs for the empirical literature on the effects of BITs on FDI are therefore difficult to pinpoint. On the one hand, as described above, there are reasons to believe that BITs, in general, are of secondary importance in determining FDI. On the other hand, it is counter-intuitive to assume that unavailability of BITs text has no effect on the investment climate, and on the decisions of investors. Empirically, missing text of agreements resulted in the literature using counts for the existence of BITs rather than indicators reflecting the variation of protection granted to investors. In other studies, MITs resulted in reduced sample size. As MITs texts are not randomly distributed across countries, MITs are likely to have a nonnegligible effect on results. Even if treaties are available, in the majority of cases the texts are found in only one language. This hinders a detailed analysis of their provisions, especially if the language is not a 'lingua franca' (e.g. English) or any other commonly used language.

A plausible explanation of the conclusion of IIAs could be found outside economic theories. In the case of developed countries, Bonnitcha, Poulsen, and Waibel have identified four potential political reasons to explain the negotiations of IIAs, ${ }^{31}$ including the promotion of business interests; ${ }^{32}$ the 'de-politicization' of investment disputes; $^{33}$ an attempt to assist in the consolidation of the international minimum standard' (IMS) as customary international law on investment; ${ }^{34}$ and the use of these treaties for diplomatic or symbolic reasons. ${ }^{35}$

After reviewing different historical moments in the creation and design of investment treaties during the past century, they conclude that corporate interests were

29 See Poulsen, above n 21.

30 World Bank, World Development Report 2005: A Better Investment Climate for Everyone (The World Bank, 2004).

31 See Bonnitcha, Poulsen, and Waibel, above n 2, at 181-206.

32 Gus van Harten, Investment Treaty Arbitration and Public Law (New York: Oxford University Press, 2008); See Allee and Peinhardt, above n 23, Delegating Differences.

33 Ibrahim F. I. Shihata, 'Towards a Greater Depoliticization of Investment Disputes: The Roles of ICSID and MIGA', 1 ICSID Review 1 (1986), at 1; Noel Maurer, The Empire Trap: The Rise and Fall of U.S. Intervention to Protect American Property Overseas, 1893-2013 (Princeton, New Jersey: Princeton University Press, 2013).

34 Andrew T. Guzman, 'Why LDCs Sign Treaties that Hurt them: Explaining the Popularity of Bilateral Investment Treaties', 38 Virginia Journal of International Law (1998), at 639; Rodrigo Polanco Lazo, 'The No of Tokyo Revisited: Or How Developed Countries Learned to Start Worrying and Love the Calvo Doctrine', 1 ICSID Review 30 (2015), at 172.

35 Eric Neumayer, 'Self-Interest, Foreign Need, and Good Governance: Are Bilateral Investment Treaty Programs Similar to Aid Allocation?', 3 Foreign Policy Analysis 2 (2006), at 245; Emma Aisbett and Lauge Poulsen, 'Relative Treatment of Aliens: Firm-Level Evidence from Developing Countries', Global Economic Governance (GEG) Programme, University of Oxford, GEG Working Paper 122, December 2016, at 32 . 
not the main drivers of IIAs, and de-politicization played a limited role in the development of BITs programmes by Western countries. ${ }^{36}$ Similarly, even if one would agree in the view that BITs were concluded to strengthen the view that the IMS was part of customary international law (mainly as a response to the 'New International Economic Order'), the extent to which that strategy was successful is highly disputed. $^{37}$ They also provide anecdotal evidence regarding the use of IIAs for diplomatic reasons or as symbols of a closer relationship between countries.

Regarding developing countries, Bonnitcha, Poulsen, and Waibel have identified three possible reasons for why these countries adopted investment treaties, ${ }^{38}$ including the promotion of foreign investment as a way of 'competing for capital'; 39 to lock-in domestic reforms; ${ }^{40}$ and also for diplomatic or symbolic reasons. ${ }^{41}$ As we have described before, the question of whether IIAs promote foreign investment as 'signal' or 'commitment' is a highly contentious one, and even if that was the interest of developing countries, it is not clear how careful, strategic or even capable they were to choose that path. Similarly, even if one would claim that IIAs were concluded tying in or pushing forward reforms, there is not sufficient evidence available to suggest that the implementation of these treaties triggered changes in domestic regulation. ${ }^{42}$ Although there is also anecdotal evidence that IIAs could also be signed for other motives, like cement diplomatic relations between two countries, or in some cases even as a merely photo-opportunity for pure political reasons, that would not be enough to explain the vast numbers of agreements we have today. This suggests that countries seemingly believe that investment agreements have an effect on investment flows.

As we have seen, political explanations for the negotiation of investment treaties, are neither conclusive nor applicable in the same way to developed or developing countries (as it also happens with economic theories). However, they could help us to at least partially understand the phenomenon of missing investment treaties, which we will detail in the next chapter.

\section{SEARCHING FOR MITS}

Currently, there is no comprehensive database of IIAs. The most complete IIAs database is maintained by UNCTAD, which by February 2018 includes information of 3619 IIAs signed, however lacking texts for 462 treaties (around 13\% of the total).

36 See Bonnitcha, Poulsen, and Waibel, above n 2, at 192, 198.

37 Ibid, at 200.

38 Ibid, at 207-32.

39 Zachary Elkins, Andrew T. Guzman and Beth A. Simmons, 'Competing for Capital: The Diffusion of Bilateral Investment Treaties, 1960-2000’, 4 International Organization 60 (2006), at 811. José E. Alvarez, 'A BIT on Custom', 42 NYU Journal of International Law and Politics (2009), at 17.

40 Mark S. Manger, Investing in Protection: The Politics of Preferential Trade Agreements between North and South (Cambridge, UK; New York: Cambridge University Press, 2009); Roberto Echandi, 'What Do Developing Countries Expect from the International Investment Regime?', in José E Alvarez and Karl P Sauvant (eds), The Evolving International Investment Regime (New York: Oxford University Press, 2011) 3-21.

41 Srividya Jandhyala, Witold J. Henisz and Edward D. Mansfield, 'Three Waves of BITs: The Global Diffusion of Foreign Investment Policy', 6 Journal of Conflict Resolution 55 (2011), at 1047.

42 See Bonnitcha, Poulsen, and Waibel, above n 2, at 215-16, 220. 
From this group of agreements, 443 are BITs — of which 160 are in force, and 19 are other treaties with investment provisions (TIPs), 7 of them in force. ${ }^{43}$

We became aware of the existence of MITs when we tried to find IIAs missing from UNCTAD's and other databases, in the framework of the SNIS-funded Project 'Diffusion of International Law: A Textual Analysis of International Investment Agreements'. That project aimed to complement existing efforts with the set-up of the Electronic Database of Investment Treaties (EDIT), which includes available texts of IIAs in one single language (English) and format (XML). ${ }^{44}$

As a first step, it was necessary to agree on a definition of what we understood as an IIA. For our purposes we defined an international investment agreement as a treaty concluded under international law between two or more states or economies, which, in whole or in part, contains substantive obligations to protect and/or liberalize foreign investment either generally or sector specific. This notion includes BITs, investment chapters of preferential trade agreements (PTAs) and Regional Investment Treaties (RITs) that have been traditionally included in existing databases. It also includes some agreements that are normally not classified as such, like Friendship, Commerce, and Navigation Agreements (FCNs $)^{45}$ and parts of PTAs outside of their investment chapter (relevant parts on services, financial services and taxation) and side or additional agreements on investment. Instead, this definition does not cover other types of agreements that have been included in existing databases some multilateral agreements (e.g. ICSID, Mauritius Convention, GATS, TRIMs), US Trade and Investment Framework Agreements (TIFAs) and EU Framework Agreements on Economic Cooperation, ${ }^{46}$ because they largely do not provide substantive binding commitments to promote, protect and/or liberalize foreign investment.

Table 1 shows that, even after a large 'treaty-hunting' that took place over a twoyears period (2015-2017) — using the methodology described in the next section, there is still a number of IIAs which texts are not available on public, private, national or international databases, and not even on governmental webpages.

Few IIAs included in EDIT are not listed in UNCTAD or any other database. Similarly, a small number of available treaties is incomplete, being largely PTAs or RTAs, which are only included in databases with their investment chapter, omitting relevant parts of the same agreement that are applicable to an investment such as chapters relating to trade in services, financial services and general exceptions including taxation issues.

Therefore, we consider that MITs are those IIAs that have been concluded by States, but their texts (and in some cases their existence) is not publicly available or

43 See UNCTAD, above n 16. By December 2015, the same database included information of 3475 IIAs signed, missing 903 treaty texts (26\% of the total).

44 Swiss Network of International Studies (SNIS) project, 'Diffusion of International Law: A Textual Analysis of International Investment Agreements', https://snis.ch/project/diffusion-of-international-law/ (visited 27 March 2018).

45 EDIT does not include FCNs concluded previous the World War II, as they had only limited investment protections.

46 EDIT includes EU all preferential trade agreements with investment provisions, even pre-Lisbon Agreements as some included liberalization obligations. 
Table 1. EDIT database

\begin{tabular}{llllllll}
\hline Type & $\mathrm{N}$ & Force & Force $\%$ & Miss & Miss $\%$ & MissForce & MissForce \% \\
\hline BIT & 3,163 & 2,527 & 79.89 & 183 & 5.79 & 22 & 0.70 \\
FCN & 46 & 46 & 100 & 0 & 0 & 0 & 0 \\
OIA & 312 & 262 & 83.97 & 8 & 2.56 & 5 & 1.60 \\
All & 3521 & 2835 & 80.52 & 191 & 5.42 & 27 & 0.77 \\
\hline
\end{tabular}

This table shows the composition of the EDIT database. The column Miss reports the total number of treaties for which, even after extensive search, no text could be found. As indicated by the column MissForce, only 22 of the 183 missing BITs are in force.

incomplete. MITs are not part of the most important databases, nor are they easily accessible online, nor in official governmental documents or libraries, including the UN treaty depository.

\section{A. Methodology}

The search of IIAs for the set-up of EDIT was performed between November 2015 and October 2017, looking for the official texts of agreements concluded until December 2016, regardless of them being in force or not, although the ratification status was considered for the purposes of MITs determinants.

In order to obtain a consolidated list of IIAs and its texts, a standardized three steps research procedure was followed:

i. Searching in existing public and private databases, both digital and physical. $^{47}$

ii. Searching in governmental websites and in international organizations websites (e.g. United Nations, World Bank, OECD). For that purpose, a comprehensive list of 139 different websites of ministries, agencies and public institutions was developed, after extensive inspection of websites.

iii. Formally contacting governments in order to obtain a copy of the official text of the agreement.

As the overwhelming majority of IIAs and MITs were concentrated on bilateral investment treaties, for the purpose of this article, we have taken only into consideration all signed BITs, and exclude Other Investment Agreements (OIAs) that are not BITs but which are part of EDIT, like FCN and PTAs with investment chapters. Also, considering that the purpose of the study is to identify the existence of MITs, availability of terminated and renegotiated BIT was also included in the sample.

47 The main databases used to populate our database are the following: UNCTAD's International Investment Agreements [http://investmentpolicyhub.unctad.org/IIA], United Nations Treaty Collection [https://treaties.un.org/], Kluwer Arbitration 'BITs' [http://www.kluwerarbitration.com/CommonUI/ BITs-countries.aspx], Oxford's 'Investment Claims' [http://oxia.ouplaw.com/\#], Investor-Law Guide ISLG [http://www.investorstatelawguide.com/], Investment Treaty Arbitration - ITA [http://www.ita law.com/investment-treaties], and ICSID's 'Investment Laws of the World' (only in printed loose-leaf) (all visited 27 March 2018). 


\section{B. Challenges finding MITs}

The major difficulties we encountered during our quest to retrieve MITs were:

i. IIAs are a moving target. New treaties are signed every year to an average of 38 treaties during the past three years. Existing databases have updated their content, addressing the gap of the MITs. For example, by early 2015, UNCTAD reported 3489 IIAs with 817 missing texts (386 of them in force). After an important update on 22 September 2016, UNCTAD reported 3604 IIAs, 491 without text (187 in force). ${ }^{48}$

ii. Information about IIAs is not always available. During this research, the authors have acknowledged that sometimes the very existence of an investment treaty is publicly unknown, due to several reasons: First, some governmental websites or official repositories are often incomplete or only include a list of agreements without providing their text. ${ }^{49}$ Second, for a number of countries (mostly developing ones), the official government website has not been updated and does not include more recent treaties, such as is the case of Mauritania, ${ }^{50}$ Senegal, ${ }^{51}$ and Jordan. ${ }^{52}$ Third, texts of IIAs are difficult to find even on dedicated websites of Investment Promotion Agencies (IPAs) that are supposed to promote IIAs. ${ }^{53}$ In contrast, double taxation agreements (DTAs) in general are easily found. ${ }^{54}$ This could imply that host States (developed and developing alike) perceive the DTAs as more relevant instruments to attract foreign investment. Fourth, several countries tend to make public only those IIAs that are in force, and this factor can be signalled as one important determinant of

These changes have important effects on our analysis. For example, until the latest update of UNCTAD database, the text of $18-19 \%$ of BITs in force signed by Finland and Sweden were unavailable. Today All Finnish BITs are available on UNCTAD and only $7 \%$ of Swedish BITs are missing.

49 The most notable example is the list of the bilateral investment agreements referred to in Article 4(1) of Regulation (EU) No 1219/2012 of the European Parliament and of the Council of 12 December 2012 establishing transitional arrangements for bilateral investment agreements between Member States and third countries, which contains a full list of BITs concluded by EU member states, but no text of them. Other examples of mere lists of IIAs are: Burkina Faso http://www.apexb.bf/les-accords-bilateraux-regis sant-les-exportations, Cuba https://cubatravelcorp.wordpress.com/2016/01/03/acuerdos-de-promociony-proteccion-reciproca-de-inversiones-appri/, Mozambique http://www.inm.gov.mz/?q=pt-pt/centrode-promo\%C3\%A7\%C3\%A3o-de-investimentos-cpi, and Yemen http://investinyemen.org/ all (visited 6 December 2017).

50 Mauritania, Ministry of Economy and Finance, General Directorate of Private Sector Promotion http:// www.investinmauritania.gov.mr/spip.php?article93 (visited 6 December 2017).

51 République du Sénégal. Primature Secrétariat General du Gouvernement, http://www.jo.gouv.sn (visited 6 December 2017).

52 As of June 2017, the website on which the Jordanian government published its investment agreements is no longer available. On the website of the Jordanian Department for International Trade, there is a link mentioned for investment agreements which is also not available http://mit.gov.jo/Pages/viewpage.aspx? pageID=309 (visited 6 December 2017).

53 Some IPAs that have published their domestic legislation with regard to the treatment of foreign investment (Investment Codes) but remain silent on the signed IIAs. See the example of Cambodia: Council for the Development of Cambodia http://www.cambodiainvestment.gov.kh (visited 6 December 2017).

54 Kuwait has even some BITs included among their database on DTAs http://www.mof.gov.kw/ MOFAgreements/MOFAgreementsDetail.aspx\#mofAgg1 (visited 6 December 2017). 
MITs. ${ }^{55}$ Finally, when contacting public officials, some governments were reluctant to share information, and either denied access to the texts or never answered our requests.

iii. Civil unrest or disturbances strife seem to influence treaty availability. For the countries that are facing civil unrest such as Libya, ${ }^{56}$ Sudan, ${ }^{57}$ Syria, ${ }^{58}$ Yemen, ${ }^{59}$ and Afghanistan, ${ }^{60}$ it was largely not possible to find the IIAs through their governmental websites but through their treaty partners. ${ }^{61}$ The non-publication of IIAs is, however, not only limited to countries associated with civil disturbances.

iv. Countries of certain regions and development status are more prone to have MITs. A wide range of African countries of developing or leastdeveloped status have an important number of their IIAs not available to public, although in some cases these treaties are available through the governmental websites of their treaty partners. This is the case of Benin, ${ }^{62}$ the Democratic Republic of Congo, ${ }^{63}$ Djibouti, ${ }^{64}$ Equatorial Guinea, ${ }^{65}$

55 For example, all BITs signed by Côte d'Ivoire which are not in force, are not only missing on UNCTAD's database but also on the websites of the partner countries. Singapore does not publish its BITs which are not in force, and notes that IIAs with Colombia, Burkina Faso, Côte d'Ivoire, Mozambique and Nigeria have been signed, but are not yet into force https://www.mti.gov.sg/ MTIInsights/Pages/IIAs.aspx. The same holds true for Mauritius: < http://www.investmauritius.com/ downloads/ippa.aspx $>$ both (visited 6 December 2017).

56 For example, the 2001 Libya-Ukraine BIT could be found through Ukraine http://www.ukrexport.gov. ua/i/imgsupload/libya and the 2003 Libya-Malta BIT through Malta https://foreignaffairs.gov.mt/en/ Treaties\%20Series/Pages/Treaties\%20Search\%20Page.aspx both (visited 6 December 2017).

57 The 1997 China-Sudan BIT could be retrieved through China http://tfs.mofcom.gov.cn/aarticle/h/aw/ 201002/20100206778963.html (visited 6 December 2017).

58 The 2002 Syria-Ukraine BIT could be found through Ukraine http://www.ukrexport.gov.ua/i/imgsup load/sirya, the 1998 Iran-Syria BIT through Iran http://rc.majlis.ir/fa/law/show/93875 all (visited 6 March 2017).

59 The 2001 Ukraine-Yemen BIT could be retrieved through Ukraine http://zakon3.rada.gov.ua/laws/ show/887_006?test=4/UMfPEGznhheI8.ZiG1Y8TkHI4mss80msh8Ie6, the 1998 China-Yemen BIT through China http://tfs.mofcom.gov.cn/aarticle/h/at/201002/20100206778924.html, the 1998 Malaysia-Yemen BIT through Malaysia http://www.miti.gov.my/miti/resources/auto\%20download \%20images/5567e08baf761.pdf all (visited 6 December 2017).

60 The 2006 Afghanistan-Iran BIT could be found through Iran http://rc.majlis.ir/fa/law/show/97998 (visited 6 December 2017).

61 For example, the 1999 Malaysia-Senegal BIT could be retrieved through Malaysia http://www.miti.gov. my/miti/resources/auto\%20download\%20images/5567e0a00527c.pdf (visited 6 December 2017).

62 The 2008 Benin-Kuwait BIT could be found through Kuwait http://www.mof.gov.kw/TaxationFAQ/ AgreementViewer.aspx?pdfpath=Benin//231fd9d9-bele-49ff-9c4f-26c19578e320.pdf (visited 6 December 2017).

63 The 2000 Democratic Republic of the Congo-Ukraine BIT could be retrieved through Ukraine http://arbitra tion.kiev.ua/uploads/kucher/16.\%20Congo\%20-\%20UKR.pdf (visited 6 December 2017).

64 The 2009 Djibouti-Kuwait BIT could be found through Kuwait http://www.mof.gov.kw/TaxationFAQ/ AgreementViewer.aspx?pdfpath=Djibouti//9f7b40a2-99a7-4f3c-bcf3-b05ac31d2335.pdf, （visited 6 December 2017).

65 The 2015 Equatorial Guinea-Ukraine BIT could be found through Ukraine http://arbitration.kiev.ua/ uploads/kucher/23.\%20Equatorial\%20G\%20-\%20UKR.pdf and the 2005 China-Equatorial Guinea BIT could be retrieved through China http://tfs.mofcom.gov.cn/aarticle/h/aw/201002/20100206785036. html both (visited 6 December 2017). 
Gabon, ${ }^{66}$ Guinea, ${ }^{67}$ Malawi, ${ }^{68}$ Mauritania, ${ }^{69}$ Mozambique, ${ }^{70}$ Namibia, ${ }^{71}$ Nigeria, ${ }^{72}$ Zambia, $^{73}$ and Zimbabwe. ${ }^{74}$ It must be noted that the lack of publicly available IIAs goes beyond the suspected countries on the African continent and unstable states. Furthermore, it seems that countries that are less open to the global market economy are also reluctant to provide information about their signed agreements, such as North Korea ${ }^{75}$ and Cuba. ${ }^{76}$ For a number of Caribbean countries there is few data available, such as Guyana and Haiti. Overall, Least-Developed Countries (LDCs) are the most recurrent countries without publicly available text of IIAs.

v. Some IIAs are wrongly indexed or duplicated in existing databases. There is also a number of BITs that do not contain any investment related provisions but are named as such. Those include double taxation agreements, ${ }^{77}$ economic cooperation

66 The 1979 Gabon-Romania BIT could be retrieved through Romania www.mae.ro/sites/default/files/tra tate/descarcare.php?doc=2282_44.var, and the 1997 China-Gabon through China http://tfs.mofcom. gov.cn/aarticle/h/aw/201002/20100206778962.html both (visited 6 December 2017).

67 The 1996 Guinea-Malaysia BIT could be retrieved through Malaysia http://www.miti.gov.my/miti/ resources/auto\%20download\%20images/5567e070248a5.pdf (visited 6 December 2017).

68 The 1995 Malawi-Taiwan BIT could be retrieved through Taiwan http://no06.mofa.gov.tw/mofa treatys/ (visited 6 December 2017).

69 The 1988 Mauritania-Romania BIT could be found through Romania http://www.cdep.ro/pls/legis/ legis_pck.htp_act_text?idt=10993 (visited 6 December 2017).

70 The 2001 China-Mozambique BIT could be retrieved through China http://www.fdi.gov.cn/ 1800000121_39_2387_0_7.html (visited 6 December 2017).

71 The 1994 Malaysia-Namibia BIT could be retrieved through Malaysia http://www.miti.gov.my/miti/ resources/auto\%20download\%20images/5567e053e17fe.pdf (visited 6 December 2017).

72 The 2002 Nigeria-Sweden BIT could be found through Sweden http://www.regeringen.se/contentas sets/eb52242e93124fb6afe43987bb2d38c9/avtal-med-nigeria-om-omsesidigt-framjande-och-skydd-avinvesteringar, and the 1994 Nigeria-Taiwan BIT through Taiwan http://no06.mofa.gov.tw/mofatreatys/ both (visited 6 December 2017).

73 The 2015 Mauritius-Zambia BIT could be retrieved through Mauritius http://www.investmauritius. com/downloads/ippa.aspx (visited 6 December 2017).

74 The 1999 Italy-Zimbabwe BIT could be found through Italy http://www.gazzettaufficiale.it/do/atto/ serie_generale/caricaPdf?cdimg $=001$ G016000200010110001\&dgu=2001-04-12\&art.dataPubblicazione Gazzetta=2001-04-12\&art.codiceRedazionale=001G0160\&art.num =1\&art.tiposerie $=S G, \quad$ the 1999 Iran-Zimbabwe through Iran http://rc.majlis.ir/fa/law/show/98003?keyword=\%D8\%B2\%DB\%8C\%D9 \%85\%D8\%A8\%D8\%A7\%D8\%A8\%D9\%88\%D9\%87, the 2000 Kuwait-Zimbabwe BIT through Kuwait http://www.mof.gov.kw/TaxationFAQ/AgreementViewer.aspx?pdfpath=Zimbabwe//488blace-18ba413c-93fe-7eddfe7ef17a.pdf, and the 1994 Malaysia-Zimbabwe BIT through Malaysia http://www.miti. gov.my/miti/resources/auto\%20download\%20images/5567e050ab25a.pdf, all (visited 6 December 2017).

75 The 1998 North Korea-Malaysia BIT could be found through Malaysia http://www.miti.gov.my/miti/ resources/auto\%20download\%20images/5567e08677e42.pdf (visited 6 December 2017).

76 The 1998 Bulgaria-Cuba BIT could be retrieved through Bulgaria http://old.mi.government.bg/trade/re gional/docs.html?id=90602 (visited 6 December 2017).

77 For example, UNCTAD lists BITs concluded by Qatar with Mauritania, Syria, Sudan and Yemen, but these agreements are in fact DTAs. See the 2003 Mauritania-Qatar http://www.almeezan.qa/ AgreementsPage.aspx?id=1787\&language $=$ ar, the 2003 Qatar-Syria http://www.almeezan.qa/ AgreementsPage.aspx?id=1250\&language $=$ ar, the 1998 Qatar-Sudan BIT http://www.almeezan.qa/ AgreementsPage.aspx?id=1520\&language $=a r$, and the 2000 Qatar-Yemen http://www.almeezan.qa/ AgreementsPage.aspx?id=1255\&language $=$ ar, all (visited 6 December 2017). Similarly, the 2001 Kuwait-Syria BIT is not a BIT, but a DTA http://www.mof.gov.kw/TaxationFAQ/AgreementViewer. aspx?pdfpath=Syria//394d9a14-ad28-448f-b63d-30a4986aec42.pdf (visited 6 December 2017). 
agreements, ${ }^{78}$ Memoranda of Understanding, ${ }^{79}$ among others. ${ }^{80}$ Some agreements were listed as two separate treaties, whereas in reality these had identical texts. This was the case for treaties signed by countries that split up in various states (e.g. Serbia and Montenegro and other countries that formed Yugoslavia). Finally, some errors in the metadata of BITs (date of signature, date of entry into force), also made difficult to locate the treaties. ${ }^{81}$

\section{DETERMINANTS OF MITS}

This section describes which countries have the most MITs and offers possible reasons why particularly the texts of IIAs from these countries are missing.

\section{A. Descriptive statistics}

For each of the 3163 BITs listed in EDIT we checked if the text of the treaty is available in the UNCTAD database. ${ }^{82} 16 \%$ of the unique BITs listed in EDIT are missing in the UNCTAD database. Interestingly, $50 \%$ of the missing treaties are BITs that are/have been in force.

If BITs would be missing at random, we could expect a specific country to have the average share of missing treaties given the total number of signed BITs by this country is not too small. This does not correspond to the practice. For instance, both Iran and Kuwait have signed more than 65 BITs, but the text of those treaties is missing in the UNCTAD database on $43 \%$ and $30 \%$ occasions, respectively. As it can be seen in Figure 1, for some countries almost all BITs are available while for others a substantial amount of treaties is not available to the public. Given that BITs are usually signed by two countries, whether they become available to the public depends on characteristics of both countries. A visualization of the network of missing treaties reveals the presence of a few countries that have a high of missing treaties (Figure 2).

Tables 2 and 3 break down the missing treaties according to geographical characteristics and World Bank Development Indicators (WDI) income group of the signatories. Table 2 illustrates that 499 of the 3163 BITs are signed among countries in the North (North America, Oceania, and Europe) and 834 between one country in

78 The 1996 Armenia-Turkmenistan is not a BIT, but two agreements: one on cooperation in the field of public health and the other on exchange of legal information http://www.parliament.am/ (visited 6 December 2017).

79 The 2000 Indonesia-Venezuela BIT is not a BIT, but a Memorandum of Understanding for the implementation of bilateral consultations http://treaty.kemlu.go.id/uploads-pub/1904_VEN-2000-0005\%20. pdf (visited 6 December 2017).

80 The 2006 Djibouti-Italy BIT is not a BIT, although it is titled as such. It is an agreement for converting debt into public investments http://itra.esteri.it/Ricerca_Documenti/wfrmRicerca_Documenti.aspx (visited 6 December 2017).

81 On some occasions, the signature date of the BIT is not correctly mentioned in the UNCTAD database, such as the Slovenia-Uzbekistan BIT (10 April 2003 instead of 7 October 2003), and the BangladeshPakistan BIT (signed 13 October 1998, not 24 October 1995).

82 EDIT lists unique treaties while in UNCTAD certain BITs are listed multiple times, e.g. BITs signed by former countries of the Union of Soviet Socialist Republics (USSR). This explains the discrepancy in the total number of signed treaties between the two databases. 


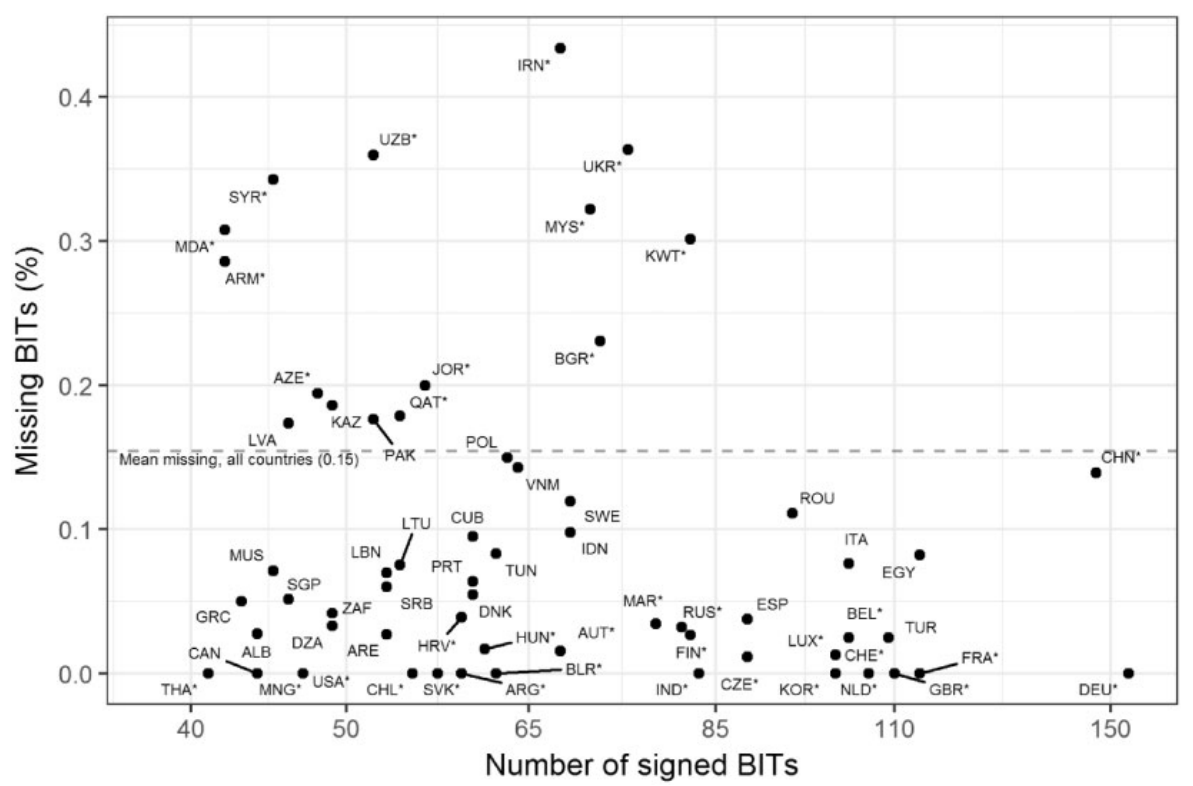

Figure 1. Missing treaties, the usual suspects $(1 / 2)$.

This figure displays the proportion of missing treaties for countries that have signed more than 40 BITs. Missing BITs are defined as treaties that have no text available in the UNCTAD database. The average share of missing treaties per country is indicated by the horizontal dashed line. The star on the names indicates whether, for a given country, its share of missing treaties is statistically different from the average. P-values are obtained using a binomial distribution with $n$ being the number of signed BITs and $p$ the share of missing treaties in the data, $15 \%$.

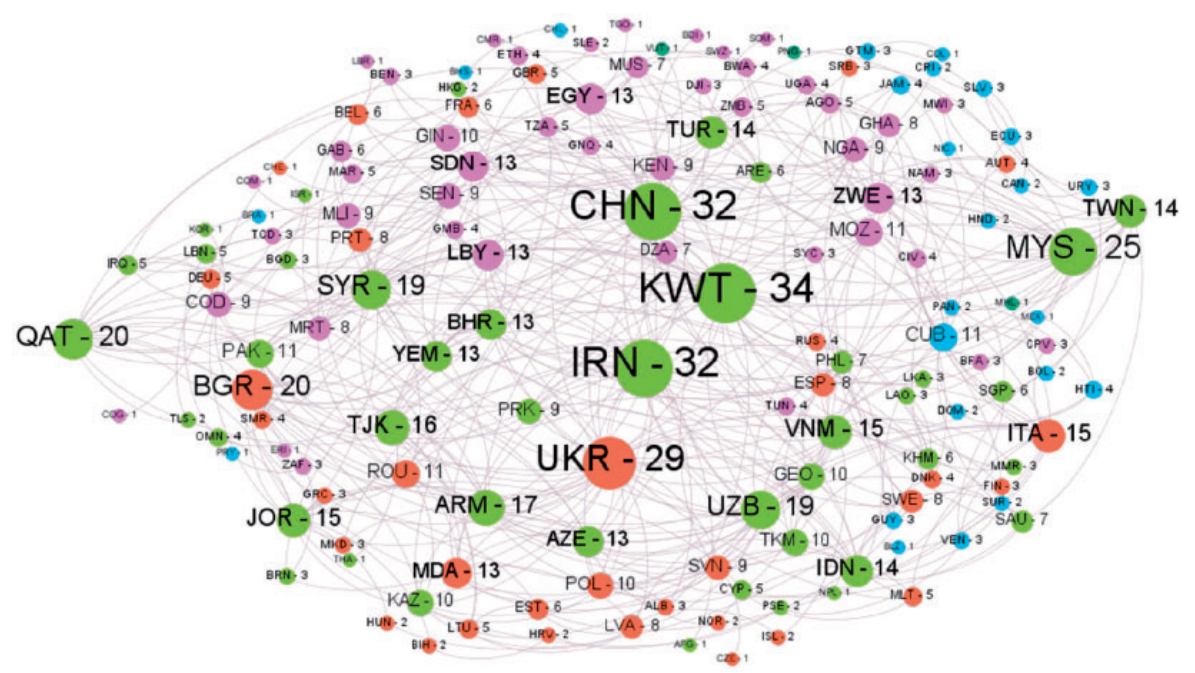

Figure 2. Missing treaties, the usual suspects $(2 / 2)$.

This figure displays the network of missing treaties. Missing BITs are defined as treaties that have no text in the UNCTAD database. The counts correspond to the total number of missing treaties, per country. 
Table 2. Missing BITs, by regional coverage

\begin{tabular}{llllllll}
\hline Region & $\mathrm{N}$ & Force & Force $\%$ & $\mathrm{~N}$, miss & $\mathrm{N}$, miss\% & Force, miss & Force, miss\% \\
\hline North & 499 & 477 & 95.59 & 35 & 7.01 & 31 & 6.50 \\
Africa & 169 & 46 & 27.22 & 51 & 30.18 & 9 & 19.57 \\
Africa-S. America/Car & 27 & 13 & 48.15 & 8 & 29.63 & 3 & 23.08 \\
Africa-Asia & 260 & 135 & 51.92 & 90 & 34.62 & 27 & 20 \\
Africa-North & 430 & 342 & 79.53 & 48 & 11.16 & 14 & 4.09 \\
S. America/Car & 94 & 68 & 72.34 & 14 & 14.89 & 2 & 2.94 \\
S. America/Car-Asia & 103 & 76 & 73.79 & 14 & 13.59 & 4 & 5.26 \\
S .America/Car-North & 323 & 281 & 87 & 7 & 2.17 & 2 & 0.71 \\
Asia & 424 & 333 & 78.54 & 127 & 29.95 & 78 & 23.42 \\
Asia-North & 834 & 756 & 90.65 & 101 & 12.11 & 69 & 9.13 \\
All & 3163 & 2527 & 79.89 & 495 & 15.65 & 239 & 9.46
\end{tabular}

Missing BITs are defined as treaties that have no text available in the UNCTAD database. The column $N$ reports the number of signed treaties, Force the subset of $N$ in force. $N$, miss and $N$, miss \% report the number and percentage of missing treaties. In order to avoid double counting, only BITs listed in EDIT are included. Region indicates regional coverage. North includes N. America, Oceania, and Europe. As reported in the last column, the text of the treaty is missing for approximately $23 \%$ of BITs in force signed between two Asian countries or between an African country and a country in South America/Caribbean.

Table 3. Missing BITs, by income group

\begin{tabular}{llllllll}
\hline GDP per capita & $\mathrm{N}$ & Force & Force $\%$ & $\mathrm{~N}$, miss & $\mathrm{N}$, miss\% & Force, miss & Force, miss\% \\
\hline High|High & 441 & 419 & 95.01 & 27 & 6.12 & 20 & 4.77 \\
High|Low & 175 & 123 & 70.29 & 32 & 18.29 & 7 & 5.69 \\
High|Middle & 1602 & 1392 & 86.89 & 174 & 10.86 & 96 & 6.90 \\
Low|Low & 22 & 1 & 4.55 & 13 & 59.09 & 0 & 0 \\
Low|Middle & 166 & 58 & 34.94 & 60 & 36.14 & 16 & 27.59 \\
Middle|Middle & 757 & 534 & 70.54 & 189 & 24.97 & 100 & 18.73 \\
All & 3163 & 2527 & 79.89 & 495 & 15.65 & 239 & 9.46 \\
\hline
\end{tabular}

Missing BITs are defined as treaties that have no text available in the UNCTAD or any other public database, or governmental website. The column $N$ reports the number of signed treaties, Force the subset of $N$ in force. $N$, miss and $N$, miss \% report the number and percentage of missing treaties. In order to avoid double counting, only BITs listed in EDIT are included. GDP per capita indicates the income group of the signatories, as defined by the World Bank's World Development Indicators (WDI).

the North and one country in Asia. Remarkably, only $27 \%$ of signed BITs among African countries are in force. Treaties signed by an Asian and an African country are most likely to be missing (35\%). However, only $20 \%$ of BITs in force between countries belonging to these two geographical regions are missing. When considering only BITs in force, the most likely treaties to be missing are the ones signed between two Asian countries and between an African and a country from South America/ Caribbean (23\%). 
About 1602 of the 3163 BITs in EDIT are signed by countries classified as high income with middle-income countries (using the WDI classification). The second most common group are BITs signed by two middle-income countries with $70 \%$ of their treaties in force. Treaties signed between two low-income countries are the least common with 22 agreements and only one in force. Approximately $28 \%$ of BITs in force are signed by one low and one middle-income country and $19 \%$ of BITs in force signed by two middle-income countries are missing in the UNCTAD database (Figure 2).

\section{B. Missing text explanatory variables}

This section investigates whether pairs of countries having signed BITs that have no next in the UNCTAD database have, on average, specific characteristics. Based on literature, we consider a set of categorical and numerical socio-economic indicators that are theoretically related to the existence of BITs between countries. We investigate whether those variables are also related to missing texts. Summary statistics are displayed in Table 4. These explanatory variables include:

i. Regional coverage dummies using data from the World Bank's World Development Indicators (WDI). ${ }^{83}$ We collapsed North America, Oceania, and Europe into a single category, denominated North. In the models, BITs signed between North countries are the regional coverage category of reference, and account for approximately $17 \%$ of the observations.

ii. In force: a binary indicator that takes the value of 1 if the treaty is in force. Treaties are published in governmental publications only after entry into force, and therefore we expect treaties that are not in force to be more likely to be missing.

iii. Gross domestic product (GDP): measured at purchasing power parity, both per capita and total, in logs, using data from the WDI. For both variables, we computed the sum of the values for the two countries and construct an asymmetry index, which allows us to capture economic size differences and differences in the level of development. The index is computed as Sym $=\left(1-\left(\frac{y_{1}}{y_{1}+y_{2}}\right)^{2}-\left(\frac{y_{2}}{y_{1}+y_{2}}\right)^{2}\right) * 100$ and therefore takes values between 0 (asymmetry) and 0.5 (perfect symmetry). In order to maximize data coverage, we took the mean, for each country, of all data points available between 2006 and 2015. Due to GDP missing data the sample is reduced to 2987 BITs. FDI flows between larger countries are generally higher than between smaller countries. Therefore, we may expect BITs signed by small countries to be more likely to be missing, given that BITs may be negotiated for purposes that are not strictly economic. Similarly, we expect countries having lower GDP per capita to be on average more likely to fail to make BITs available, because of lack of resources. 


\begin{tabular}{|c|c|c|c|c|c|c|c|}
\hline & Min. & 1st Qu. & Median & Mean & 3rd Qu. & Max. & Sd \\
\hline Africa & 0 & 0 & 0 & 0.05 & 0 & 1 & 0.23 \\
\hline Africa-S.America/Carr & 0 & 0 & 0 & 0.01 & 0 & 1 & 0.08 \\
\hline Africa-Asia & 0 & 0 & 0 & 0.08 & 0 & 1 & 0.27 \\
\hline Africa-North & 0 & 0 & 0 & 0.14 & 0 & 1 & 0.35 \\
\hline S.America/Carr & 0 & 0 & 0 & 0.02 & 0 & 1 & 0.15 \\
\hline S.America/Carr-Asia & 0 & 0 & 0 & 0.03 & 0 & 1 & 0.16 \\
\hline S.America/Carr-North & 0 & 0 & 0 & 0.10 & 0 & 1 & 0.30 \\
\hline Asia & 0 & 0 & 0 & 0.13 & 0 & 1 & 0.33 \\
\hline Asia-North & 0 & 0 & 0 & 0.27 & 1 & 1 & 0.44 \\
\hline In force dummy & 0 & 1 & 1 & 0.81 & 1 & 1 & 0.40 \\
\hline GDP (Sum, log) & 2.07 & 6.10 & 6.89 & 6.95 & 7.81 & 9.89 & 1.30 \\
\hline GDP (Sym) & 0.01 & 7.30 & 21.93 & 23.78 & 40.72 & 50 & 17.15 \\
\hline GDP per capita (Sum, log) & 7.69 & 10.27 & 10.71 & 10.58 & 10.96 & 12.09 & 0.63 \\
\hline GDP per capita (Sym) & 2.26 & 24.09 & 37.86 & 34.27 & 46.28 & 50 & 13.56 \\
\hline Post-1997 & 0 & 0 & 0 & 0.50 & 1 & 1 & 0.50 \\
\hline Post-1997* In-Force & 0 & 0 & 0 & 0.34 & 1 & 1 & 0.47 \\
\hline $\begin{array}{l}\text { Percentage raw mat in } \\
\text { exports (Sum) }\end{array}$ & 0 & 17.26 & 33.67 & 42.55 & 65.22 & 167.90 & 31.57 \\
\hline $\begin{array}{l}\text { Percentage raw mat in exports } \\
(\text { Sum })^{*} \text { In-Force }\end{array}$ & 0 & 8.57 & 22.68 & 32.66 & 47.91 & 167.90 & 31.46 \\
\hline $\begin{array}{l}\text { Percentage raw mat in exports } \\
\quad(\text { Sum }) * \text { Post- } 1997\end{array}$ & 0 & 0 & 0 & 23.47 & 37.88 & 166.17 & 33.56 \\
\hline $\begin{array}{l}\text { Percentage raw mat in } \\
\text { exports (Sym) }\end{array}$ & 0 & 20.50 & 35.46 & 31.87 & 46 & 50 & 15.69 \\
\hline $\begin{array}{l}\text { Percentage raw mat in exports } \\
(\mathrm{Sym})^{*} \text { In-Force }\end{array}$ & 0 & 4.61 & 30.09 & 26.29 & 44.68 & 50 & 18.84 \\
\hline $\begin{array}{l}\text { Percentage raw mat in exports } \\
(\text { Sym })^{*} \text { Post }-1997\end{array}$ & 0 & 0 & 0 & 15.28 & 33.95 & 50 & 19.02 \\
\hline Control of Corruption (Sum) & 7.29 & 9.25 & 10.34 & 10.34 & 11.34 & 14.28 & 1.33 \\
\hline Control of Corruption (Sym) & 44.30 & 48.27 & 49.36 & 48.90 & 49.86 & 50 & 1.19 \\
\hline Political stability (Sum) & 4.91 & 9.14 & 10.04 & 9.91 & 10.80 & 12.58 & 1.25 \\
\hline Political stability (Sym) & 39.74 & 48.77 & 49.57 & 49.05 & 49.91 & 50 & 1.41 \\
\hline Rule of law (Sum) & 7.12 & 9.52 & 10.56 & 10.46 & 11.37 & 13.66 & 1.27 \\
\hline Rule of law (Sym) & 43.20 & 48.33 & 49.35 & 48.93 & 49.83 & 50 & 1.14 \\
\hline Regulatory quality (Sum) & 6.28 & 9.74 & 10.74 & 10.63 & 11.53 & 13.86 & 1.27 \\
\hline Regulatory quality (Sym) & 41.40 & 48.63 & 49.46 & 49.03 & 49.86 & 50 & 1.19 \\
\hline
\end{tabular}

iv. Signed after 1997: a binary indicator that takes the value of 1 if the treaty is signed after 1997, which is the starting year of the first North American Free Trade Agreement (NAFTA) investor-State arbitration claim (Azinian $v$ Mexico), around 20 years ago. The decision only came out two years later, but the case already triggered some fears about ISDS, especially as in the 
same year, other two cases were filed (Ethyl $v$ Canada and Metalclad $v$ Mexico). This prompted a series of investment arbitration disputes which in 1998 for the first time reached more than 10 cases, a tendency that increased almost every year. Approximately 50\% of BITs were signed after the year 1997.

v. The percentage of oil and raw materials in total exports of merchandize. The variable is included both as sum and asymmetry index, computed as for GDP. In order to maximize data coverage, we take the mean, for each country, of all data points available between 2006 and 2015. Data from the WDI. The correlation of these variables with missing BITs texts is unclear as, on the one hand, we could expect countries relying on natural resources to be more likely to be willing to attract investors. At the same time, however, countries might prefer not to advertise rights granted to investors that are already operating in their countries.

vi. A set of indicators for the institutional quality of countries, from the World Bank's World Governance Indicators. ${ }^{84}$ In order to make interpretation of results easier, we rescaled the data such that all observations are positive. The variables were included both as the sum of the values of the two parties and in its asymmetry index, as described for GDP. We selected four indicators:

a. Political stability and absence of violence. BITs are signed with the objective of promoting and protecting investment, and therefore can be considered to be more important for countries with higher risk of civil strife and low levels of political stability.

b. Rule of law. This indicator captures perceptions 'of the extent to which agents have confidence in and abide by the rules of society, and in particular the quality of contract enforcement, property rights, the police, and the courts, as well as the likelihood of crime and violence'. ${ }^{85}$

c. Regulatory quality. This indicator reflects to which extent governments implement policies that foster the development of the private sectors. It is constructed using information including trade policy, easy of doing business, competition law, and investment freedom.

d. Control of corruption. Provides data about the extent of private and business interest's influence on policies implemented by governments.

Given the general nature of the indicators, and their high correlation (Pearson correlations between 0.6 and 0.9 ), they are included separately in the models as a measure to test the robustness of the relationship between institutional quality and missing BITs texts.

Table 5 displays the results. ${ }^{86}$ In all six models the dependent variable is a binary indicator that takes the value of one when the BIT text is missing from the UNCTAD database and zero otherwise. Significance levels are based on

84 See World Bank's Governance Indicators: http://info.worldbank.org/governance/wgi/pdf/rl.pdf (visited 6 December 2017).

85 Ibid.

86 All results are obtained using: R Core Team (2016). R: A language and environment for statistical computing. R Foundation for Statistical Computing, Vienna, Austria https://www.R-project.org/ (visited 6 December 2017). 


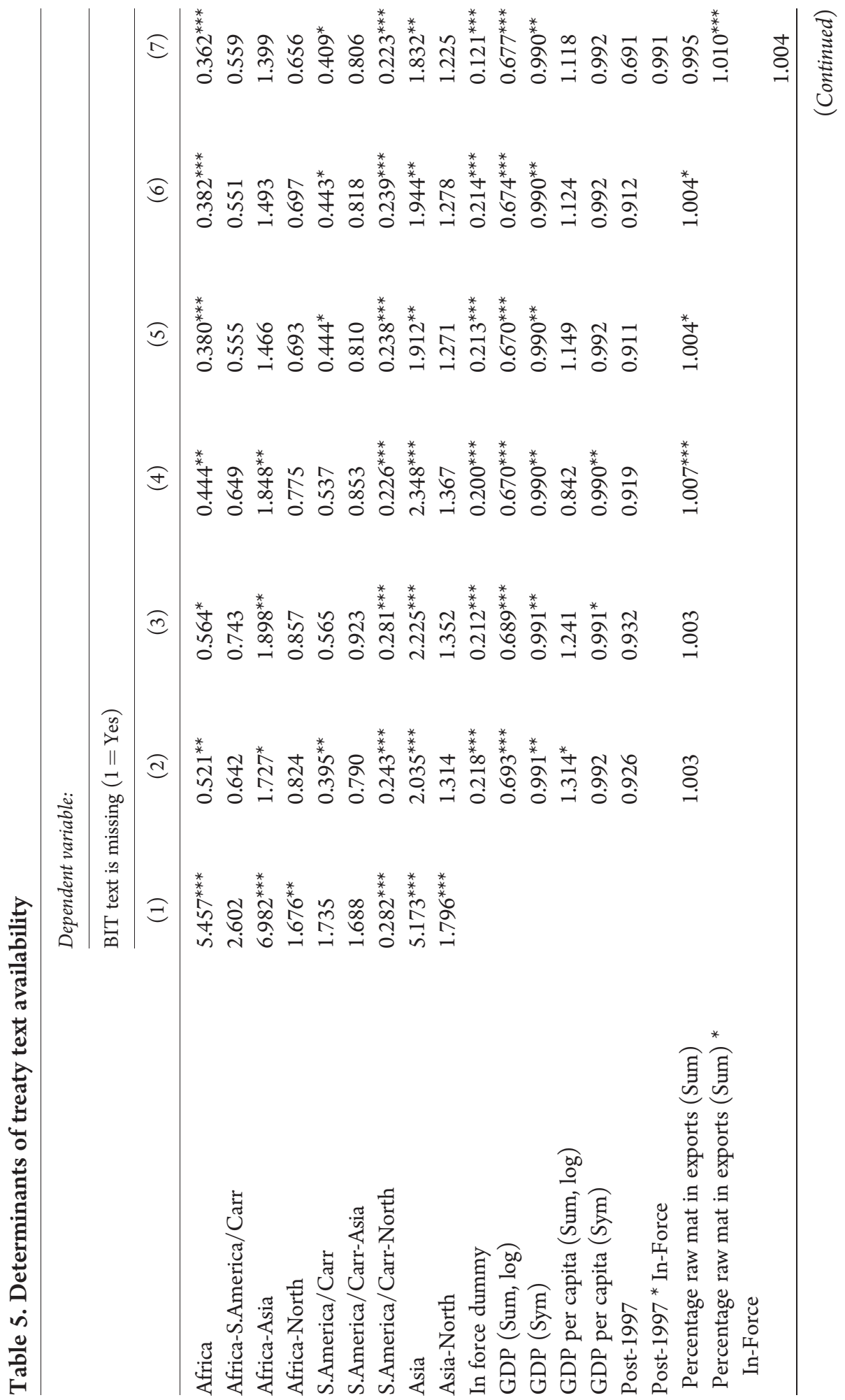




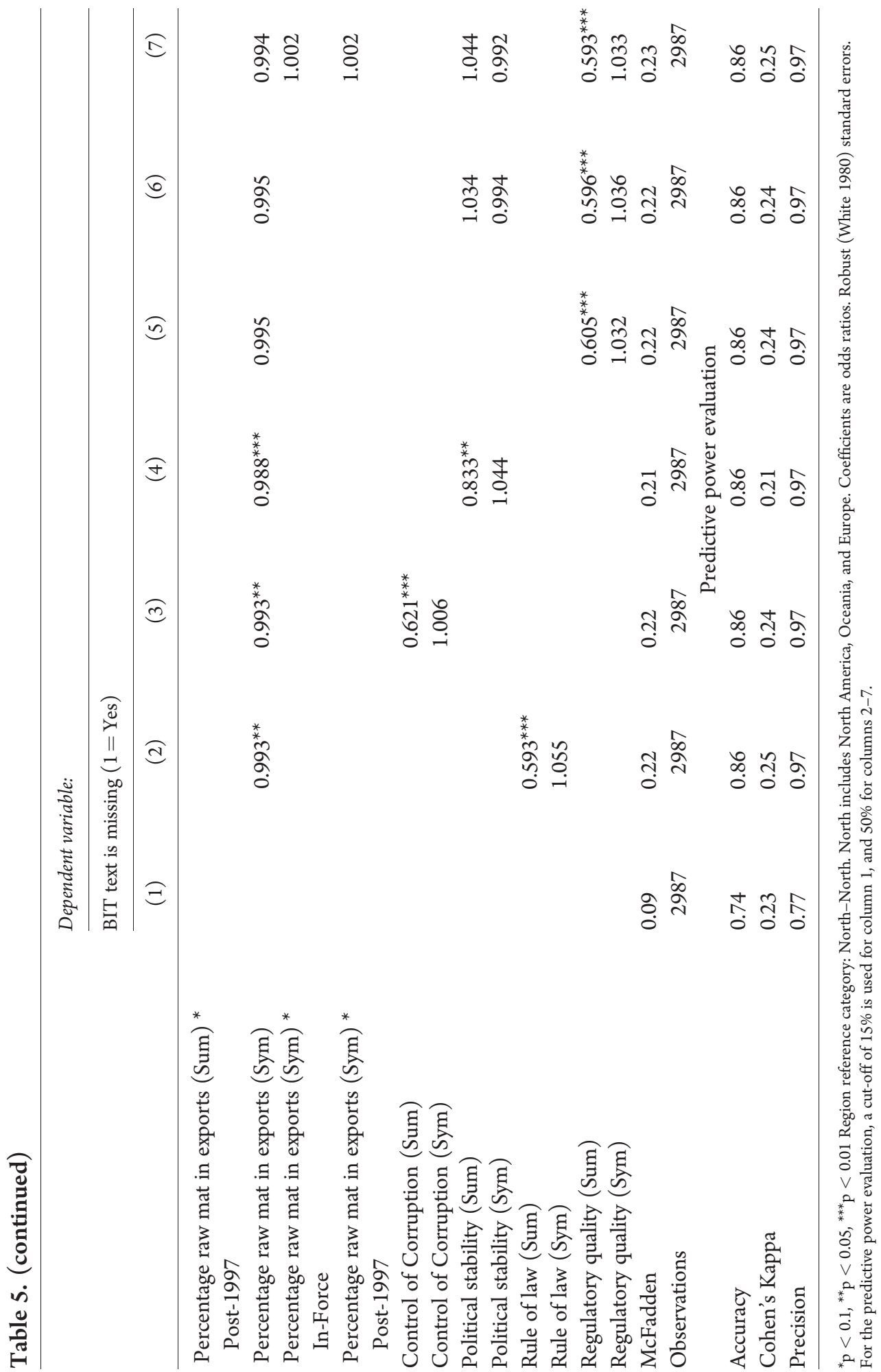


heteroscedastic robust standard errors. ${ }^{87}$ All models are estimated using logistic regression. The advantage of this type of regression is that it restricts predicted values between 0 and 1 . In other words, the model returns a value, for each observation, between 0 and 1 , which corresponds to the predicted probability of the text of the BIT being missing.

After appropriate transformation, the coefficients of a logistic regression are to be interpreted as odds ratios. Therefore, variables are positively correlated with missing BITs text if the reported coefficient is larger than one, and negatively if smaller than one. The odds of an outcome is defined as the probability of the outcome occuring (the text of the BITs is missing), over the probability of the outcome not occuring (the text of the BITs is available): Odds $=\frac{P(Y=1)}{P(Y=0)}=\frac{P(B I T \text { is missing })}{P(B I T \text { is available })}$. For instance, the odds of a treaty signed by two North countries being missing are 7/93 $=0.07$ (see Table 2). Similarly, for a treaty signed by a country in Asia and one belonging to the region North, the odds are $12 / 88=0.14$. The odds ratio is therefore defined as the ratio of two odds, in this case: $\frac{(12 / 88)}{(7 / 93)}=1.8$. In simple words, treaties signed by a country in Asia and one belonging to the global North are 1.8 times more likely to be missing than treaties signed by two countries both belonging to the global North. The odds for all regions, relative to North (the category of reference), are reported in column 1 of Table 5. The coefficient on Asia/North is 1.796, slightly smaller than 1.8. Such differences are the result of having dropped some observations due to missing data.

In columns $2-5$ in Table 5 additional indicators are included in the model. As expected, whether a treaty is in force is an important determinant of whether the text of the treaty is available in the UNCTAD database. Switching from not in force to in force, the odds of the treaty being missing change by factor 0.2 . In other words, treaties in force are five times more likely to be available than treaties not in force. Cumulative economic size of countries also has a strong negative effect on the probability of BITs being missing, meaning that on average missing BITs concern treaties signed by smaller countries. Interestingly, as indicated by the coefficient on GDP (Sym), for a given level of cumulative GDP, a treaty is less likely to be missing if the two countries have similar size. These relationships are highly significant in all estimated models. The coefficients on GDP per capita instead, are generally not statistically different from 1 . It is interesting to remark that the introduction of GDP and quality of institutions variables result in major changes in magnitude and sign of several regional indicators. In the case of treaties signed by African countries among themselves, the coefficients become statistically smaller than 1 . This implies that differences estimated in column 1 are mainly due to economic factors. In the case of

87 Heteroscedasticity refers to the circumstance in which the variability of a variable is unequal across the range of values of a second variable that predicts it. Results remain virtually unchanged by clustering the errors at the regional coverage level. White (1980) errors obtained using the option HCO in the 'sandwich' package. Achim Zeileis, 'Econometric Computing with HC and HAC Covariances Matrix Estimators', 11(10) Journal of Statistical Software (2004), 1-17. http://www.jstatsoft.org/v11/i10/ (visited 6 December 2017). Achim Zeileis, 'Object-Oriented Computation of Sandwich Estimators', 16(9) Journal of Statistical Software (2006), 1-16 http://www.jstatsoft.org/v16/i09/ (visited 6 December 2017). 
treaties signed by Asian countries among themselves instead, the magnitude of the coefficients is reduced, but the direction of the correlation remains the same.

There is no quantitative evidence for whether treaties signed before or after 1997 are more likely to be missing. The sign of the coefficient on Post-1997 indicates a negative correlation, but it is never statistically significant from 1 . Instead, there is some evidence for a relationship between the percentage content or raw materials and oil in exports and missing BITs text. The estimated effect for the sum of raw materials is positive and statistically larger than 1 in columns 4 and 5. Similarly, the results provide some support for the hypothesis that BITs signed by two countries having asymmetric natural resource endowments are more likely to be missing. The magnitude of the coefficients is small, but significant in columns 2, 3 and 4, at least at the $5 \%$ level.

The correlation between the four institutional quality indicators and the odds of the BITs text being missing is negative, large in magnitude, and highly significant. Differences in the quality of institutions between signatories are instead not found to be correlated with BITs text availability. One theory claims that countries sign BITs to signal, ex-ante, commitments they are willing to make to foreign investors. In practice we observe that, controlling for level of GDP and thus resources, it is precisely treaties signed by countries having lower quality of institutions that are missing from public databases. This seems at odds with the stated objectives of BITs. In addition, the results hints at the relationship between public governance and investment law by questioning to which extent governments disclose information concerning the regulation of foreign investments.

Of the four institutional quality indicators, political stability and regulatory quality display the lowest correlation. We include both of them in column 6 of Table 5 to test their explanatory power. The coefficient on political stability changes sign and loses statistical significance. In column 7 instead, we test whether the level and difference in natural resource endowments are particularly important when the BIT is either in force or has been signed after 1997. This is done, in practice, by interacting the relevant variables. The magnitude of the coefficient on the In-Force variable increases from 0.20 to 0.12 ; the coefficient on the sum of raw materials changes sign and loses significance, while its interaction with In-Force has a positive and, although small in magnitude, highly significant effect on the odds of the BITs text being missing. In other words, for a given percentage of cumulative raw materials in exports, the text of a treaty is more likely to be missing if it is in force. This results is surprising, as generally treaties that are in force are more likely to be available, and appears to be inconsistent with the 'signalling' and 'commitment' theories advanced in the literature.

The results described in this chapter should not be interpreted as causal effects, given the likely correlation of the explanatory variables with the error term, due to omitted variable bias. The estimation of causal effects is crucial when analysing the effects of a policy instrument, for instance whether BITs actually increase FDI flows between countries. In this article, the focus is not on whether improving institutional quality results in countries being more transparent about their foreign investment policy. Rather, the emphasis is on whether the text of BITs is available to be public is systematically related to the socio-economic characteristics of the countries involved. 
Thus, we interpret these results as reflecting the variety of strategic, political, and economic reasons that motivate states to negotiate BITs in the first place.

To conclude this section, we proffer a short evaluation of the predictive power of the models (see Table 5). As mentioned above, logistic regression returns a predicted probability for the BITs text being missing, based on the explanatory variables and the estimated coefficients. Such probabilities can be transformed into a dichotomous indicator using a cut-off and compared to the actual status of the treaty, as observed in the UNCTAD database. Accuracy, for instance, measures the percentage of observations that are correctly predicted, and is 74\% column 1 and $86 \%$ for columns 2-7. Cohen's Kappa is an indicator that is especially useful when the categories are not balanced, as in our case (only approximately $15 \%$ of treaties are missing). When evaluating a model, this performance measure also takes in consideration that a category with few observations is more likely to have more miss-classifications. Finally, precision indicates the percentage of treaties predicted to be missing by the model that are actually missing in the UNCTAD database.

\section{LANGUAGE AVAILABILITY}

After determining how many investment treaties are 'missing' and what the possible causes are of their lack of availability, we now turn to the treaties that are publicly available but enjoy a limited diffusion due to the language(s) in which they are publicly found. In this section we examine in how many and which languages the BITs can be obtained.

Although, from reading their final provisions, we know that investment treaties are usually signed in more than language; on average, when BITs are available, in $81 \%$ of cases they are available in only one language (see Table 6, third column, last row).

When a treaty is available in only one language, it can either be the language of one of the countries, a common language, or a language of a third party. Treaties signed between an Asian and an African country are the most likely to be available only in the language of one country. A large group of countries have their IIAs largely available only in their own official language, such as Armenia, ${ }^{88}$ Belarus, ${ }^{89}$ Indonesia, ${ }^{90}$ Iran, ${ }^{91}$ Moldova, ${ }^{92}$ Mongolia, ${ }^{93}$ Qatar, ${ }^{94}$ Serbia, ${ }^{95}$ and Vietnam. ${ }^{96}$ Other countries do have the text of their IIAs available in English, but they are only accessible after navigating several pages in their official language making difficult to find them if the researcher is not aware of the translation in that

88 National Assembly of the Republic of Armenia http://www.parliament.am (visited 6 December 2017).

89 Legislation of the Republic of Belarus, http://naviny.org (visited 6 December 2017).

90 Basis Data Perjanjian Internasional http://treaty.kemlu.go.id/index.php/treaty/index (visited 6 December 2017).

91 Islamic Parliament Research Center of the Islamic Republic of Iran http://rc.majlis.ir/fa/law/ (visited 6 December 2017).

92 Registrul de Stat. Al Actelor Juridice Al Republicii Moldova http://lex.justice.md (visited 6 December 2017).

93 Legal Info Mongolia http://www.legalinfo.mn/law (visited 6 December 2017).

94 Qatar Legal Portal http://www.almeezan.qa (visited 6 December 2017).

95 National Serbian Goods and Services Market, http://www.trzistesrbije.com (visited 6 December 2017).

96 Vietnam, Ministry of Foreign Affairs, Directorate of State Protocol https://stateprotocol.mofa.gov.vn (visited 6 December 2017). 
Table 6. Language availability, by region

\begin{tabular}{lllllll}
\hline Region & Available & 1Lang & 1Lang \% & 3rd \% & Common \% & Either \% \\
\hline North & 464 & 366 & 79 & 58 & 2 & 43 \\
Africa & 118 & 109 & 92 & 15 & 28 & 57 \\
Africa-S. America/Car & 19 & 16 & 84 & 25 & 12 & 62 \\
Africa-Asia & 170 & 154 & 91 & 42 & 23 & 35 \\
Africa-North & 382 & 299 & 78 & 29 & 14 & 58 \\
S. America/Car & 80 & 70 & 88 & 1 & 89 & 10 \\
S. America/Car-Asia & 89 & 76 & 85 & 50 & 1 & 49 \\
S. America/Car-North & 316 & 233 & 74 & 29 & 13 & 59 \\
Asia & 297 & 257 & 87 & 62 & 5 & 33 \\
Asia-North & 733 & 578 & 79 & 58 & 3 & 40 \\
All & 2668 & 2158 & 81 & 46 & 11 & 44 \\
\hline
\end{tabular}

This table reports in which language treaties are available in the UNCTAD database. Available indicates the total number of signed treaties that are available in at least one language. 1Lang reports the count of treaties available only in one language, 1 Lang $\%$ the percentage. The remaining columns break down the composition of 1 Lang into:

Percentage of treaties available in a third language $(3 r d)$;

Percentage of treaties available in a common (official) language (Common);

Percentage of treaties available in either official language (Either).

For instance, 366 (79\%) BITs signed by countries in the North are available in only one language. $43 \%$ of them are available only in the official language of one of the parties.

language. This is notably the case of member countries of the European Union (among others: Bulgaria, ${ }^{97}$ Denmark, ${ }^{98}$ Finland, ${ }^{99}$ Greece, ${ }^{100}$ Italy, ${ }^{101}$ Latvia, ${ }^{102}$ Lithuania, ${ }^{103}$ Portugal, ${ }^{104}$ Spain, ${ }^{105}$ and Sweden), ${ }^{106}$ as well as countries like Norway, ${ }^{107}$ and South Korea. ${ }^{108}$

Table 7 provides statistics for treaties that are available in only one language, restricting the analysis to cases in which the language of the treaty is one of the languages of the two parties (common language cases are excluded).

Treaties signed between an Asian country and a country in the North are most likely to be available in a third language. $77 \%$ of treaties available in English in the UNCTAD database are only found in English, and 65\% of those use English as a lingua franca. Countries like China, Latvia, United Arab Emirates, and Algeria have the

97 Republic of Bulgaria, Ministry of Economy http://mi.government.bg/en (visited 6 December 2017).

98 Retsinformation.dk https://www.retsinformation.dk (visited 6 December 2017).

99 Finlex Data Bank http://www.finlex.fi/en (visited 6 December 2017).

100 Hellenic Parliament http://www.hellenicparliament.gr/ (visited 6 December 2017).

101 Italy, Archivio dei Trattati Internazionali Online http://itra.esteri.it/Ricerca_Documenti/ wfrmRicerca_Documenti.aspx (visited 6 December 2017).

102 https://www.vestnesis.lv (visited 6 March 2017).

103 https://www.urm.lt/default/en/foreign-policy/treaties/bilateral (visited 6 March 2017).

104 Portugal, Diário da República Electronico, https://dre.pt (visited 6 December 2017).

105 Spain, Acuerdos de Promoción y Protección Recíproca de Inversiones (APPRIs) http://www.comer cio.es/acuerdos (visited 6 December 2017).

106 Regeringskansliet http://www.regeringen.se (visited 6 December 2017).

107 Norges traktater https://lovdata.no/register/traktater (visited 6 December 2017).

108 Ministry of Foreign Affairs, Republic of Korea http://www.mofa.go.kr/trade/treatylaw/treatyinforma tion $/$ bilateral $/$ index.jsp?menu=m_30_50_40\&tabmenu=t_1 (visited 6 December 2017). 
Table 7. BITs available in the official language of only one party

\begin{tabular}{llllcc}
\hline Party1-Party2 & $\mathrm{N}$ & Party1 & Party2 & Party1\% & Party2\% \\
\hline Africa-S. America/Car & 10 & 2 & 8 & 20 & 80 \\
Africa-Asia & 54 & 38 & 16 & 70.37 & 29.63 \\
Africa-North & 172 & 76 & 96 & 44.19 & 55.81 \\
S. America/Car-Asia & 37 & 33 & 4 & 89.19 & 10.81 \\
S. America/Car-North & 137 & 59 & 78 & 43.07 & 56.93 \\
Asia-North & 233 & 68 & 165 & 29.18 & 70.82 \\
High-Low & 64 & 27 & 37 & 42.19 & 57.81 \\
High-Middle & 480 & 315 & 165 & 65.62 & 34.38 \\
Low-Middle & 62 & 48 & 14 & 77.42 & 22.58 \\
\hline
\end{tabular}

This table illustrates whether BITs tend to be available, in the UNCTAD database, in the official language of countries from specific regions or income groups. Analysis is therefore restricted to BITs available in only the official language of one party, excluding country pairs sharing a common official language.

majority of their IIAs available in English. All Canadian IIAs are bilinguals and the large majority of Swiss BITs too (but are found in French or English, not in German or Italian). Overall, the most common IIAs languages are English, French, Spanish, Arabic, Russian, and German.

\section{COMMON PROVISIONS OF COUNTRIES WITH MITS}

Even after extensive search, the text of many agreements could not be found. The countries with the highest number of MITs in absolute terms are: Qatar (12 out of 55 treaties), Kuwait (12 out of 90), Turkey (11 out of 119), Cuba (9 out of 61), Mali (9 out of 22), Zimbabwe (9 out of 37), Sudan ( 8 out of 36), Syria ( 8 out of 47), Italy (7 out of 107), Ghana (6 out of 29), Iran (5 out of 71) and Libya (5 out of $44)$. Some other countries show a high number of missing treaties relative to the total number of IIAs they have signed. These are: Mali (41\%), Iraq (40\%), TimorLeste (33\%), Seychelles (29\%), Botswana (27\%), the Democratic Republic of Congo (26\%), Angola (23\%), Djibouti (23\%), Somalia (20\%), Occupied Palestinian Territory (20\%), Suriname (17\%), and lastly, Sierra Leone (14\%).

This section identifies which treaty standards are most common in the treaty practice of the above-mentioned countries with the highest number of MITs. The idea is to provide an overall view whether the countries with the largest MITs share some common features in their IIAs that are publicly available, that could help to explain their number of MITs.

Available IIAs concluded by the countries with the largest MITs shows that many of their IIAs include the same standards as in traditional IIAs, with some particularities:

- These IIAs include broad definitions of investment and investor, except Iran which requires legal entities to have substantial business activities in the contracting treaty 
partner (73\% of Iran's IIAs). The agreements also provide broad standards of treatment.

- Only Turkey (65\%) and Kuwait (54\%) have limited their national treatment standard to investors 'in like circumstances'.

- While most countries include a full protection and security standard, Timor-Leste provides this treatment only 'in accordance with its national laws'; and Italy does not include such clause at all (65\%).

- With regard to compensation for expropriation, only Seychelles has the practice to carve out the regulatory measures that are taken for the public welfare (40\%).

- Seychelles (80\%) and Iraq (40\%) are the only countries that limit the free transfer of funds due to Balance-of-Payments or macro-economic difficulties.

- Only Kuwait prohibits performance requirements in its IIA practice (63\%).

- Countries with more 'public policy' space in their IIAs that include exception clauses are: Qatar (43\% includes an essential security exception), the Occupied Palestinian Territory and Somalia (50\% includes a general exception clause to protect human, animal and plant life).

- Finally, most countries allow any dispute to be submitted to ISDS, except Ghana which permits only treaty claims $(73 \%)$.

Regarding the consistency of IIA practice of countries with the largest MITs, we conclude that their available agreements do not have substantial differences with those concluded by countries that do not have a large number of MITs. In the majority of cases these treaties include: asset-based definition of investment and broad definition of investor; apply to investments before and after entry into force; MFN and NT cover the post-establishment phase; include unqualified FET and FPS; compensation for direct indirect expropriation, as well as for strife; free transfer of funds without limitation; and both ISDS and State to State Dispute Settlement.

One could assume that treaties that are missing are different than treaties that are available, but from the experience of the MITs that we managed to retrieve during the set-up of EDIT, we can infer that these treaties probably are not systematically different to the average IIAs. For that reason, other possible explanations for the presence of MITs are advanced in this article.

\section{REASONS THAT EXPLAIN MISSING INVESTMENT TREATIES}

We have detected that an important share of texts of IIAs cannot be retrieved easily, and often requires searches in official publications of governments, which very frequently implies dealing with language differences. Even for OECD countries, designated offices for the advertisement of BITs seem to be the exception rather than the rule, resulting in the texts of BITs missing from common databases used by investors and researchers alike. For countries that rank either among the top 20 in outflows or inflow FDI according to UNCTAD, ${ }^{109}$ missing text in BITs is not an exception. China is the most prominent example, with $20 \%$ of texts not publicly available (29 treaties out of 145, including 13 treaties in force, 13 signed and 3 terminated). 
According to our research, there are several factors that are likely to influence the absence of publicly available texts of investment treaties.

i. Date of Entry into Force: IIAs that are not in force are less likely to be available to the public. Treaties that are not in force are not printed on government publications and several countries consistently do not make them available until they are in vigour.

ii. Regional Factor: Approximately 30\% of treaties signed between two Asian countries, between two African countries, and between an African and a country in South America/Caribbean are missing. Treaties signed by an Asian and an African country are the most likely to be missing, at $35 \%$. When considering only BITs in force, the most likely treaties to be missing are the ones signed between two Asian countries and between an African and a country from South America/Caribbean. Econometric results confirm that BITs signed by at least one Asian country are more likely to be missing. Moreover, BITs signed by countries that are geographically further away are more likely to be available.

iii. Level of Development: BITs between high-income and middle-income and by two middle-income countries are more likely to be available.

Treaties signed between two low-income countries are less likely to be available. A wide range of LDCs and developing economies do not make their IIAs available to public. These are mostly African countries and some Caribbean countries. Generally, linear regression shows that BITs signed by bigger (in terms of economic size) countries are less likely to be missing. Moreover, for a given level of total GDP, agreements are less likely to be missing if the economic size of the two countries is similar.

iv. Strategic Reasons: We hypothesize that countries that are less open to the global market economy are also reluctant to provide information about their signed agreements, such as North Korea and Cuba. Some countries seem to have a less transparent attitude, as a reaction to ISDS, after facing claims (e.g. Egypt, Iran, or South Africa). There is some evidence that BITs signed by countries that have a higher percentage of oil and raw materials in exports are more likely to be missing. The effect is more important when there is asymmetry in natural resource endowments. This seems at odds with the stated objectives of BITs to promote investment.

v. Investment Climate: For countries that are facing war or civil unrest such as Libya, Sudan, Syria, Yemen, and Afghanistan, it was almost impossible to find the IIAs through their governmental websites, but through their treaty partners. This was confirmed by econometric evidence: BITs signed by countries with low levels of Rule of Law, as measured by the World Bank Development indicators, are statistically more likely to be missing.

vi. Lack of resources/capacity/interest: For a number of countries the official government website has not been updated and does not include the more recent treaties, such as Cyprus, Jordan, Mauritania, and Senegal. Some treaties are labelled as IIAs, but they are double taxation or other agreements. This could be also explained as lack of resources or capacity, 
but also that some countries do not really care about IIAs. After an extensive examination of IPAs' websites, Yackee has concluded that BITs are never or infrequently mentioned on IPAs' webpages, and overall these treaties do not seem to be a central part of their marketing efforts. ${ }^{110}$ In some cases, it seems that the availability of IIA's texts reflects the interest of investors, particularly when the agreement is found only in the language of country of origin of the investor, implicitly assuming that investment flows go only in one direction. This could be an explanation for the practice of several European countries and South Korea, referred in the precedent section, of having the websites or IIA's repositories, largely only in their official language.

With respect of the treaties that are publicly available, the large majority of IIAs are found in one language $(81 \%)$, even though they are regularly signed in more than one. A country's level of development is a factor that influences in how many and which languages investment treaties are available. $77 \%$ of BITs signed between a low-income country and a middle-income country are available in only the official language of the low-income country.

\section{CONCLUSION}

Following 'signalling' or 'commitment' theories on IIAs, it may appear counterintuitive to negotiate and conclude international investment agreements that are meant to promote and protect foreign investment, and then not make these treaties publicly available. Similarly, it is also puzzling that often BITs are available only in languages that are rarely used in international transactions, or only in the official language of one of the contracting parties, given that BITs are supposed to be reciprocal by nature.

In this work we have identified several factors that influence whether the text of a treaty is missing in public databases. Entry into force, economic size, and the institutional quality of the parties involved, natural resource endowments, as well as strategic reasons, lack of resources or merely of interest, are all factors that are related to MITs.

The non-random existence of MITs should inform the research on IIAs, and particularly the economic literature on BITs effects of FDI, and on the determinants of BITs in the first place. How can we claim that BITs influence FDI's flows if the actual provisions included in the agreements and in some cases the existence of BITs is not known by foreign investors? In theory, a treaty intended to act as a 'credible commitment' would not necessarily require the same public availability as an agreement that is intended to 'signal' a good investment environment, but that does not explain the complete absence of treaty texts.

Furthermore, the existence of MITs and their determinants could inform the political literature on negotiation of IIAs. What determines whether countries negotiate an investment agreement? This article is based on the general assumption that IIAs have been concluded to promote investment. In practice however, there could be 
other motivations behind the negotiation of investment treaties. As pointed out in previous literature, some IIAs might have been signed with the primary goal to promote or reinforce diplomatic relations. This would partly explain the existence of MITs, but that does not tell the whole story. This article clearly demonstrates that 'missing investment treaties' do exist, and that the absence of treaty texts should be considered in future research on determinants and effects of international investment agreements. 